\title{
SINISTRALITY IN RELATION TO HIGH BLOOD PRESSURE AND DEFECTS OF SPEECH
}

\author{
CLARENCE QUINAN, M.D. \\ SAN FRANCISCO
}

INTRODCCTION

From the clinical point of view, left-handedness is usually regarded as an insignificant physical peculiarity. Various authors, it is true, point out that this affection may have a background of psychomotor symptoms, but such statements seem to have attracted very little attention. In 1870, Cooke ${ }^{1}$ declared his belief that all left-handed persons are "more or less "odd,", and this is probably a fair expression of current opinion on the subject today. It does not appear to be generally known that in addition to a simple form, there are crossed forms of left-handedness or sinistrality. The simple, familiar form may reveal itself in an individual through some deviation from the right-handed conventions. On the other hand, the crossed forms are latent and unless they are sought for they escape observation. Left-eyedness, for example, is not uncommon in the right-handed and, conversely, righteyedness is common in sinistrals. The etiology of these mixed types is obscure. Perhaps, in some instances they may be due to a compulsory change of handedness effected in early childhood. Few reports are available in the literature as to the relative numerical importance of the crossed forms, but they appear to be more prevalent than simple left-handedness.

The object of this paper is (1) to review the literature of the subject and (2) to present the results of an investigation of left-handedness in relation to high blood pressure and speech defects.

\section{REVIEW OF LITERATLRE}

In view of the fact that more or less exhaustive analyses of the literature of left-handedness are available in the papers of Beeley, ${ }^{2}$ Snith ${ }^{3}$ and others, it will suffice for the present purpose to consider previous contributions with especial reference to (a) heredity, (b) prevalence and (c) symptoms.

Heredity.-Bardeleben ${ }^{4}$ carried out extensive osteologic sțudies on

1. Cooke, R. H.: Left-Handedness, Lancet, 2:526, 1870.

2. Beeley, A. L.: Left-Handedness, Am. J. Phys. Anthrop., 2:389, 1919.

3. Smith, L. G.: A Brief Survey of Right-Handedness and Left-Handedness, Pedagogical Sem., 24:19, 1917.

4. Bardeleben. K.: Ueber bilaterale Asymetrie beim Menschen und bei höheren Tieren, Anat. Anz. 34: Ergänzungshft. 2, 1909. 
the higher anthropoid apes by means of comparative measurements of the long bones of the extremities. His results prove that, as a rule, the bones of the right side are the longer. Mollison (cited by Bardeleben) found that righthandedness is characteristic of man, the orang and the gibbon. It is most pronounced in man, less marked in the orang, and still less in the gibbon. Bardeleben states that his own results and those of Mollison show unmistakably that right-handedness and left-handedness occurs among the primates, but that the available data are inconclusive in many respects and throw very little light either on a primitive source of left-handedness or on any determining factor, aside from the general one of heredity.

Ramaley, ${ }^{5}$ from a careful analytical study of data derived from 610 parents and 1,130 children, concludes that left-handedness is a mendelian recessive, and that "the condition probably exists in about one-sixth of the population."

Lithgow "gives an account of a family in which the "eldest son for three generations at least has been left-handed."

Prevalence.-Biblical authority (Judges $\mathrm{xx}, 15-16$ ) establishes the fact that the tribe of Benjamin, which numbered about 25,000 men capable of bearing arms, had 700 left-handed soldiers who were especially skillful with the sling. In that remote age, therefore, according to this evidence, less than 3 per cent. of the male population were sinistrals.

Modern statistics are probably more trustworthy. Schaefer,' Ballard ${ }^{8}$ and Smith $^{3}$ found, respectively, 4.06, 4 and 4.5 per cent. of left-handedness from surveys of a combined total of 32,318 school children. Stier ${ }^{9}$ noted 5.1 per cent. as the proportion among 5,000 army recruits. Both Ireland ${ }^{10}$ and Smith $^{3}$ reported 11 per cent. of left-handedness from their investigations of imbecile and feebleminded children. Smith ${ }^{3}$ states that the proportion among 500 delinquents was 6 and 11 per cent., respectively, for boys and girls, whereas the proportion among 500 deaf was 4.5 per cent.

From the statistical data just given it is obvious that approximately 4 per cent. of normal people are left-handed.

Turning to the question as to the frequency of latent or crossed sinistrality, two reports are available in the literature. Ballard ${ }^{8}$ tested

5. Ramaley, F.: Inheritance of Left-Handedness, Am. Naturalist, 47:730, 1913.

6. Lithgow, R. A.: Left-Handedness, Lancet, 2:660, 1870.

7. Schaefer, M.: Die Linkshänder in den Berliner Gemeindeschulen, Berl. klin. Wchnschr., 1:295, 1911.

8. Ballard, P. B.: Sinistrality and Speech, J. Exper. Pedagogy, 1:298, 1911.

9. Stier, E.: Linkshändigkeit, besonders in der Armee, Deutsch. med. Wchnschr., 35: 1587. 1909.

10. Ireland, W. W.: Notes on Left-Handedness, Brain, 3:207, 1880. 
fifty-one left-handed people with respect to the "fixing-eye" and found that 57 per cent. of them were right-eyed and 43 per cent. were lefteyed. Hartshorne ${ }^{11}$ found nine left-eyed individuals among seventytwo right handed patients. Of three left-handed patients, he states that two proved to be right-eyed and one left-eyed.

Symptoms.-(a) Psychomotor: Stier ${ }^{9}$ emphasizes the fact that enuresis is a common symptom among sinistrals.

Ballard ${ }^{8}$ makes use of the term "dextro-sinistral" for an individual, naturally left-handed, who from early childhood has been trained to use the right hand, and he points out that many stammerers belong in this class. Stier ${ }^{-9}$ agrees with Ballard that speech disturbances are particularly common among the left-handed, and the observations of Hollis ${ }^{12}$ are in accord with this view. The statement of Liepmann ${ }^{13}$ that left hemiplegia in a sinistral is rarely accompanied by motor aphasia also is of interest in this connection.

(b) Visual: Wray ${ }^{14}$ described two ocular tests of left-handedness in the following words: "It is common knowledge that though the vision is perfect in each eye and the refraction normal, nearly every person has a master-eye; this is determined by holding a ring at arm's length with both eyes open and covering an object a few yards away. A left-eyed person on shutting his left eye will find the ring too far to his left. If, on the other hand, he shuts his right eye he finds he is dead-on his object. . . ." Another point to which reference may be made is the almost invariably superior coordination of the right hand with the right eye. To show this, facing $6 / 24$ of Snellen's type, point promptly at the middle letter with the index finger of the right hand and shut the left eye. If righthanded the pointing is accurate. Now by pointing with the left index finger in the same way it will be found the pointing is accurate if the experimenter is left-handed but inaccurate if he is right-handed."

Rosenbach, ${ }^{15}$ Baudouin, ${ }^{16}$ Enslin ${ }^{17}$ and Griesbach ${ }^{18}$ fully confirm Wray's findings.

11. Hartshorne, I.: Right-Handedness and Left-Handedness, Albany $M$. Ann., 32:338, 1911.

12. Hollis: Lopsided Generations, J. Anat. \& Physiol., 9:263, 1875.

13. Liepmann, H.: Ueber die wissenschaftlichen Grundlagen der sogenannten "Linkskultur," Deutsch. med. Wchnschr., 37:1249, 1911.

14. Wray, C.: Right-Handedness and Left-Brainedness, Lancet, 1:683 (March 7) 1903.

15. Rosenbach, O.: Ueber monokulare Vorheerschaft beim binokularen Sehen, Muench. med. Wchnschr. 2:1290 (July 28) 1903.

16. Baudouin, M.: Droiture et Gaucherie oculaires, Gaz. méd. de Par, Series 13, 4:353 (July 23) 1904.

17. Enslin: Kurze Mitteilung ueber ein Augensymptom bei Linkshändern, München. med. Wchnschr., 57:2242, 1910.

18. Griesbach, H.: Ueber Linkshändigkeit, Deutsch. med. Wchnschr., 45: 1408 (Dec. 18) 1919. 
The objective data which have been referred to in this outline of the literature seem definitely to prove: (1) that left-handedness is hereditary, and (2) that it strongly suggests a relative inferiority in the organization of the central nervous system. The evidence in support of the first point is thought to be conclusive. With regard to the second point, the relatively frequent occurrence of speech defects among the left-handed would seem to show that, in comparison with right-handed people, they find themselves at a disadvantage in the execution of finely coordinated movements. Moreover, sinistrality is exceptionally prevalent among the feebleminded.

\section{RESLLTS OF PERSONAL INVESTIGATIONS}

Technic and Results.-As a tentative theoretical basis for the work here reported, four general propositions were kept in view:

1. That left-handedness is hereditary.

2. That left-handedness implies a relative inferiority in the organization of the central nervous system.

3. That the etiology of high blood pressure is unknown.

4. That if high blood pressure may be construed as in any sense indicative of constitutional inferiority, or of stresses or maladaptation in the central nervous system, then, comparative blood pressure determinations in right-handed and left-handed individuals, about of the same age, might yield information of some value.

In order to secure practical data, blood pressure observations were made on 142 inmates of the San Francisco Home for the Aged. In this institution there are 733 ambulatory males whose ages range from 44 to 89 years. A majority of the men are over 60 , and only five men under 50 were encountered in the course of this work. Ruling out those who were rendered unavailable for examination because of loss of vision in one or both eyes, posthemiplegic contractures and other lesions, approximately 600 men were included in the survey. All of these old people live under the same conditions of housing and food.

Method of Testing.-Each man was questioned as to his handedness and as to whether he had been a stammerer in childhood or had suffered from other defects of speech. During the interrogation it was borne in mind that left-handedness may be simple or crossed and so the queries were varied to suit individual cases. In this way sinistrals were found who prefer to employ the left hand only in certain activities, and one right-handed sinistral was found who stated that although he fires a gun from the right shoulder he takes aim with the left eye. Pure sinistrals, of course, make use of the left hand practically in every manipulation. They hold a knife, spoon or pen in the left hand, fire a gun from the left shoulder, and wield various implements with the left arm and hand. 
The "master-eye" was determined in each individual by means of Wray's tests, and, as a rule, the results were definite and satisfactory. For confirmative evidence, however, I made use of a pointing test based on Ballard's "cigar-box" test. A wooden "pistol" with a barrel nine inches long was used. Each end of the barrel is furnished with a sight of fine steel wire one inch in height. The man to be tested is directed to seize the "pistol," hold it at arm's length and, with both eyes open, quickly point it at the observer and at the same time to bring the sights into line. If now the observer faces the "pistol" at a distance of twenty feet or more, it is at once apparent to him with which eye the man takes aim. The "fixing-eye" usually remains the same, irrespective of the hand in which the "pistol" is held.

Systolic blood pressure observations were made in the customary manner with Faught's instrument.

Results.-- (a) Sinistrals: In the examination for handedness of abount 600 men, forty-two sinistrals were found. These sinistrals include twenty-eight left-handed and fourteen right-handed individuals.

The visual tests led to an even division of the twenty-eight lefthanded men, as 50 per cent. of them proved to be right-eyed and 50 per cent. left-eyed. On the other hand, the fourteen right-handed men were found to be left-eyed. In view of these findings, therefore, it became possible to subdivide the original forty-two sinistrals into three equal groups, designated as: Group 1, left-handed, left-eyed, pure sinistrals; Group 2, left-handed, right-eyed, crossed sinistrals, and Group 3, right-handed, left-eyed crossed sinistrals.

Although no record of the number was kept, it seems worth while to note the fact that fully one-half of the men in Groups 2 and 3 laid claim to ambidexterity.

Five men in Group 1 and two men in Group 2 gave a history of stammering. Group 3 was negative in this respect.

(b) Dextrals: For comparison with the sinistrals, blood pressure observations were made on 100 unselected, right-handed, right-eyed dextrals. The members of this group were secured from a large assemblage of the men, in the order in which they came forward for examination, and they are in every way representative of the general body of inmates at the Home. Each man was questioned as to his handedness and his eyes were examined in the manner already described. All men thus tested who proved to be both right-handed and right-eyed were accepted as dextrals and determinations of blood pressure were made forthwith.

Five men in the dextral group gave a history of stammering.

The general results obtained in the examinations of the four groups are brought together for comparison in Tables 1 and 2 . 
Table 1.-Comparative Blood Pressure Determinations in Sinistrals, Crossed Sinistrals and Dextrals

\begin{tabular}{|c|c|c|c|c|}
\hline & \multirow[b]{2}{*}{ Mean Age } & \multicolumn{3}{|c|}{ Blood Pressure Values } \\
\hline & & $\begin{array}{c}\text { Over } \\
\text { 1o0 Mm., } \\
\text { per Cent. }\end{array}$ & $\begin{array}{l}150 \mathrm{Mm} \text {. } \\
\text { or Less, } \\
\text { per Cent. }\end{array}$ & $\begin{array}{l}\text { Mean } \\
\text { Value, } \\
\text { Mm. }\end{array}$ \\
\hline $\begin{array}{c}\text { Group 1: } 14 \text { pure sinistrals (left-handed, } \\
\text { left-eyed men) }\end{array}$ & 65.5 & 71.4 & 28.5 & 166.7 \\
\hline $\begin{array}{c}\text { Group } 2: 14 \text { crossed-sinistrals (left-handed, } \\
\text { right-eyed } \\
\text { men) }\end{array}$ & 68.2 & 85.7 & 14.2 & $18: .1$ \\
\hline $\begin{array}{c}\text { Group } 3: \text { it } \\
\text { left-eyed mensed-sinistrals (right-handed, }\end{array}$ & 63.2 & 71.4 & 985 & 114.2 \\
\hline $\begin{array}{c}\text { Group } 4: 100 \text { pure dextrals (right-handed, } \\
\text { right-eyed men) } \ldots \ldots \ldots \ldots \ldots \ldots \ldots \ldots \ldots \ldots \ldots \ldots \ldots \ldots \ldots\end{array}$ & 69.4 & 46.0 & 54.0 & 154.5 \\
\hline
\end{tabular}

TABLE 2.-Speech Defects in Sinistrals, Crossed Sinistrals and Dextrals

\begin{tabular}{|c|c|c|}
\hline & ' & $\begin{array}{l}\text { History of } \\
\text { Staminering in } \\
\text { Childhood, } \\
\text { per Cent. }\end{array}$ \\
\hline $\begin{array}{l}\text { Group } \\
\text { Group } \\
\text { Group } \\
\text { Group }\end{array}$ & 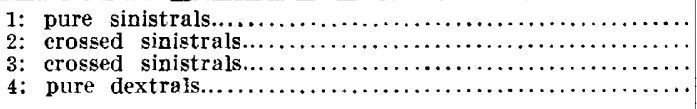 & $\begin{array}{r}3 \overline{5.7} \\
14.2 \\
0.0 \\
5.0\end{array}$ \\
\hline
\end{tabular}

SUMMARY

A survey of approximately 600 men between the ages of 44 and 89 was made with a view to determine (1) the relation of left-handedness to high blood pressure and (2) the relation of left-handedness to defects of speech. The following results were obtained:

1. Forty-two sinistrals or 7 per cent. were found. Classified with reference to the dominant or "master-eye," these sinistrals form three groups, designated as :

Group 1, left-handed, left-eyed, pure sinistrals.

Group 2, left-handed, right-eyed, crossed sinistrals.

Group 3, right-handed, left-eyed, crossed sinistrals.

2. Compared with a group of 100 right-handed, right-eyed, pure dextrals, the mean blood pressure values observed in the sinistral groups were from 7.8 to 17.8 per cent. higher.

3. A mean value of $154.5 \mathrm{~mm}$. was obtained for the dextral group. The mean value obtained for the crossed sinistrals of Group 2, was $182.1 \mathrm{~mm}$.

4. In the three sinistral groups blood pressure values higher than $150 \mathrm{~mm}$. were noted in from 71 to 85 per cent. of the men, as against 46 per cent. in the dextral group.

5. Five per cent. of the pure dextrals gave a history of stammering. The proportion in the group of pure sinistrals was 35.7 per cent. 


\section{CONCLUSIONS}

1. High arterial tension occurs more frequently in left-handed than in right-handed people.

2. In view of the evidence submitted that left-handedness is hereditary, and that it indicates a defective organization of the central nervous system, it is concluded that hereditary predisposition is a definite factor in the etiology of high blood pressure, and that high arterial tension is suggestive of constitutional inferiority.

3. As compared with dextrals, stammering occurs in sinistrals with a frequency from three to seven times greater. 